\title{
TRANSFORMATIONAL POTENTIAL OF A CLASSICAL UNIVERSITY MODEL
}

\author{
Vasyl Kremen \\ Doctor of Sciences in Philosophy, Professor \\ Full member (Academician) of the National Academy of Sciences of Ukraine \\ Full Member (Academician) of the National Academy of Educational Sciences of Ukraine \\ President of the National Academy of Educational Sciences of Ukraine, Ukraine \\ president@naps.gov.ua \\ $+380442263180$ \\ ORCID ID 0000-0001-5459-1318
}

\section{ABSTRACT}

The given article is about the major challenges of university education in the $X X I$ century. One of them is the innovative tendencies in modern civilization, which can be matched by a rapid spread of research universities. Another challenge is deep commercialization of university life in the context of globalization. Thus, entrepreneurial and corporate universities can become alternative forms of university life which are emerging in response to the above mentioned processes.

Keywords: university; research university; entrepreneurial university; corporate university; commercialization; innovative civilization.

\section{INTRODUCTION}

A contemporary university is going through a crisis, it is facing the need for radical transformations to meet the challenges of public expectations. However, following these extraordinary changes one cannot forget about traditions, continuity and humanistic principles of a university life. In the closure of the article I would like to quote Karl Jaspers whose wisdom makes sense to all of us who try to penetrate the appeal of a university and behold its purpose: "A university is impoverished if its spirit fades, if philology rules without philosophy, technical practices go without theories, endless facts run without ideas and academic discipline overcomes the spirit” (Jaspers K., 2002: p. 117).

Modern global world is a dynamic entity and a university, being one of the oldest social institutions of European civilization, cannot miss its radical dramatic and fateful changes. A few decades ago one of the leading philosophers of the XX century Hans-Georg Gadamer said: "The idea of a university, as it has developed over the last two decades, has always meant a transition from doctrina to research, in other words, to echo W. von Humboldt, a transition to science which has not been properly discovered" (Gadamer Hans-Georg, 2002: p. 170).

The purpose of the article is an analysis of the main impacts facing university education in the XXI century and the need for radical transformation of the classical model of university.

\section{METHODOLOGY}

In due time when the classical model of a university emerged from the contributions of classical German philosophers it was fundamentally thought 
over by W. von Humboldt and implemented in 1810 in the University of Berlin. As Herbert Schnedelbach said "This model was named after Wilhelm von Humboldt who defined and implemented its structure and objectives being the Head of Culture, Social Education and Medical Institutions Segment working with the title of state privy chancellor. Basic works by Schelling, Steffen, Schleiermacher and Fichte preceded the founding of the Berliner University, so we regard W. von Humboldt's approach as a synthetic product of their ideas. The Berliner University, with Fichte as the first president, emerged as an authentically new institution, and not as a reformation consequence" (The phenomenon of innovations: education, society, culture, 2008: p. 2). Wilhelm von Humboldt underscored in his "Inner and Outer Structure of Higher Educational Institutions in Berlin" that the foundation of the inner organization of a scientific institution is the principle of "science presenting something undiscovered and undiscoverable, so the search for this object is everlasting” (Humboldt W., 2002: p. 27).

The default indeterminacy of science and constant creative search excludes any dogma or ideological imparity, which is of utmost importance nowadays. So, probably this is the true mission of a classical university - to inspire constantly for further development, to discover new limits of knowledge and existence and search for defining meanings - both on the personal and social level. Education and research and two major parameters of a university activity, identified by W. von Humboldt, become an engaging intellectual activity which discloses human nature and culture and their defining purpose.

American researcher John Scott defines three basic principles which constitute the foundation of the Humboldtian classical university model; first is the unity of learning and research, second is the academic freedom which includes both the freedom to teach and the freedom to learn, and third is the selfsufficiency of the academic subjects which confirms the authenticity of research (Scott John C., 2006: p. 20). Analysis of these principles proves that the former two of them remain fundamental until now and ultimately preserve the ontological basis of the institutional nature of a university, whereas the latter, the third one, is being reconsidered, or in advanced terms - reloaded, under the circumstances of cross-field and interdisciplinary tendencies. This context seems quite relevant to the state-of-the-art existence of our civilization which tends to overcome borders.

\section{THE CLASSICAL MODEL OF THE UNIVERSITY IN TIME AND SPACE DIMENSION}

An attempt to regard the challenges of a modern classical university in time and space is undertaken by S. V. Kurbatov (Kurbatov S. V., 2014). Timewise, the major transforming factor changing the essence and nature of contemporary civilization is the innovation factor. As we earlier stated, innovations shape the destiny of the global world being the essence of post-industrial informational society which inconstancies complicate the activity of a human being... Inquiry into the phenomenon of innovation is an attempt to see ways of orientation for a human being in the unrestricted dynamics of life, an attempt to see meanings and directions defining the lifestyle in which constant change and innovations dominate (The phenomenon of innovations: education, society, culture, 2008: p. 6). In fact, the research component of the university mission has to be innovative, 
so the continual increase of its importance and role in the past decades is characteristic to university life.

The model of a research university which rests on the Humboldtian principles and approaches first emerged in the USA and later spread throughout the world. This exactly model embodies the innovative character of the modern civilization in its pure sense. The first American research universities appeared in the XIX century, for example the John Hopkins University, founded in 1876. Specialized institutions begin to appear in the XX century, their target activity is to support scientific research in strategically important government areas. Ultimately, the National Research Council was founded in 1916 and later, in 1940 the National Defense Research Council appeared.

Naturally, the American model of a research university differed from the classical German model as offered by Wilhelm von Humboldt. According to Philip Altbach the difference is three-fold: 1) service to society and its interests is declared the major value of American universities; 2) the management system turned out to be more democratic than in Europe due to grouping departments according to their majors; 3 ) administrative and managerial duties were performed by the elected members of these departments whereas top management was appointed by specific boards or the government (Altbach P. G., 2011: p. 15).

According to American researchers Richard Atkinson and William Blanpied (Aronowitz Stanley, 2000: p. 44), in 2003 one hundred American research universities held $79,6 \%$ of all research and the top ten of them held 16,9\% research. Throughout 1973-2003 university expenses on research grew quite asymmetrically, with Medicine expanding from $\$ 3$ bln. to $\$ 12$ bln., Biology growing from $\$ 3$ bln. to $\$ 7$ bln., Engineering getting from $\$ 3$ bln. to $\$ 5,6$ bln. From 1983 to 2003 the number of post-graduate students in American research universities grew from 70 thousand to 130 thousand, with almost $41 \%$ in 2003 being international students.

According to the latest Carnegie's classifications in 2010 and 2015 American research universities are divided in three groups 1) doctoral universities with the highest research activity which includes 115 universities; 2) doctoral universities with relatively high research activity which includes 107 universities; 3 ) doctoral universities with average research activity which includes 113 universities (Carnegie Classifications [Electronic resource]). Financial context of the leading research universities are impressive. Thus, Harvard, the richest American university, reported $\$ 4,5 \mathrm{bln}$. expenditure in the 2015 fiscal year with the endowment of $\$ 37,6$ bln. At that period the University had 2400 tenured professors and 10400 associates and taught more than 21000 students. In 2015-2016 the tuition fees for the students were $\$ 45278$ per year (Harvard at a Glance [Electronic resource]).

The oldest international rating, the Shanghai ranking, evaluates the performance value of research universities through its own system of indicators. The key parameter for this ranking, dating back to 2003, is the number of the Nobel Prize winners, as well as other significant winners and finalists, affiliated with the university. Also, the citation frequency and quantity of research publications in leading academic journals are considered. Ultimately, Harvard has been leading this ranking for many years and the top ten of it is represented by 8 American and 2 British universities. In 2016 the ranking's top ten was as shown in Table 1 (Academic Ranking of World Universities [Electronic resource]).

The split into countries with the leading universities represented in the Shanghai Ranking is also worth attention Table 2 (Academic Ranking of 
World Universities: Statistics [Electronic resource]). These are the most advanced countries of the modern world, which constitute its core according to Immanuel Wallerstein.

Unlike innovative research parameters of a university activity, mentioned in the early classical Humboldtian model, the major special challenges of a contemporary university appeared in the XX century and were deeply rooted in the development of entrepreneurship and increase of economic component in the activity of any institution. The process of globalization provides a powerful social and economic basis for turning any university into a transnational institution. Under these conditions getting higher education becomes a private matter of an individual leading to the corresponding economic consequences. One of the leading contemporary sociologists, University of California Berkeley professor Michael Buravoy, says that a worldwide tendency to privatization of higher education is clearly identified. In the 60-70s in the USA we had a tendency to increase of public and private universities which competed heavily. By the end of the 70 s and in the 80 s our government, led by the market, decided they could not fully support public universities because it cost too much. It led to cutting the financing of public universities and made them generate their own income (Buravoy M., 2014: p. 101-102).

Table 1

Best universities according to Academic Ranking of World Universities (ARWU) in 2016

\begin{tabular}{|c|c|c|c|}
\hline № & University & Country & Rating \\
\hline 1. & Harvard University & USA & 100 \\
\hline 2. & Stanford University & USA & 74,4 \\
\hline 3. & Cniversity of California, Berkeley & USA & 70,1 \\
\hline 4. & Cambridge & UK & 69,6 \\
\hline 5. & Massachusetts Institute of Technology (MIT) & USA & 69,2 \\
\hline 6. & Princeton University & USA & 62 \\
\hline 7. & Oxford & UK & 58,9 \\
\hline 8. & California Institute of Technology & USA & 57,8 \\
\hline 9. & Columbia University & USA & 56,7 \\
\hline 10. & Chicago University & USA & 54,2 \\
\hline
\end{tabular}

These are practically the same processes which Ukraine is currently facing. Back in 2004 Ukrainian researchers Mykola Polyiakov and Varfolomiy Savchuk stated that one of the ways to quickly respond to industrial and economic demands is an approximate "entrepreneurial university model" for technical colleges, universities and similar educational institutions. Stimulation of the "entrepreneurial university" helps universities maintain their financial status under the conditions of universal educational crisis and decrease of state support of universities being still dependent on governmental structures. This process started in Europe more than a decade ago and by now has accumulated best practices cases which are worth following (Polyakov M. V., 2004: p. 261-262).

In fact, an entrepreneurial university is an attempt to apply business models and principles in an academic setting, rebooting university life accordingly. In the 
USA a similar practice has been spread actively after Dec, $12^{\text {th }}, 1980$ when the Bayh-Dole Act was adopted; it gave universities more chances for commercial and entrepreneurial activity. At the same time research on university commercial activity started. As Frank Rothaermel, Shanti Agung and Lin Jiang say, from 1981 till 2005 more than 173 articles were published with a research on university commercial activity. Most popular issues for them were entrepreneurial research university (86 articles, constituting 50\%); starting new businesses (42 articles, constituting 24\%); ecological context and innovations (29 articles, constituting $17 \%)$. Outside of the USA 77 more articles were published (45\%): mostly in Great Britain (26), Sweden (14) and Belgium (11) (Rothaermel Frank T., 2007: p. 695-696).

Table 2

Top ten countries which universities are in the Academic Ranking of World Universities (ARWU) in 2016

\begin{tabular}{|c|c|c|c|c|c|c|}
\hline Country & Top 20 & Top 100 & Top 200 & Top 300 & Top 400 & Top 500 \\
\hline USA & 15 & 50 & 71 & 98 & 119 & 137 \\
\hline UK & 3 & 8 & 21 & 28 & 33 & 37 \\
\hline Japan & 1 & 4 & 6 & 9 & 12 & 16 \\
\hline Switzerland & 1 & 4 & 6 & 7 & 8 & 8 \\
\hline Austria & - & 6 & 8 & 14 & 21 & 23 \\
\hline Canada & - & 4 & 6 & 13 & 16 & 19 \\
\hline Germany & - & 3 & 14 & 21 & 27 & 38 \\
\hline France & - & 3 & 9 & 13 & 18 & 22 \\
\hline The Netherlands & - & 3 & 9 & 11 & 12 & 12 \\
\hline Sweden & - & 3 & 5 & 8 & 10 & 11 \\
\hline
\end{tabular}

In his eloquently titled article "When Knowledge Married Capital: The Birth of Academic Enterprise", published in 2013, one of the most influential experts in the field Henry Etzkowitz gives the following explanation of academic commercialization: "There is a certain symbiosis between knowledge and capital, different forms of capital - economic, human and intellectual - assume creating new knowledge and knowledge is fundamental in accumulating capital" (Etzkowitz Henry, 2013: p. 109).

Yet, business's entrepreneurial nature leads to outsmarting universities and setting up an alternative institution within its own framework. We are speaking about a corporate university now. A fundamental research of this type of institution is in J. Meister's works. She regards this phenomenon as a "strategic umbrella" for improving employees' education, as well as consumers' and vendors', for the sake of institutional strategies. According to forecasts this model will be most demanded in the XXI century.

The first corporate university was founded in the USA in 1956 by the famous trans-national company General Electrics. This university is still functioning. Yet, massive spread of corporate universities started in the 90-ies of the XX century. From 1993 till 2001 the number of corporate universities increased from 400 to 2000, in 2010 it reached 3700 (Hearn D. An Examination of Corporate University Model [Electronic resource]). According to the Dutch researcher M. Rademakers a quicker growth of corporate universities from the 1990-ies proves to be more than a fashionable trend. Corporate universities quickly turned from simple training 
departments to centers for transfer and exchange of knowledge and innovations both inside the company and between institutions (Rademakers M., 2005: p. 130).

Yet, contemporary researchers generate a lot of substantial criticism of a corporate university model. Stanley Aronowitz and Henry Giroux say that within a corporate culture social aspects of life are interpreted in the context of individual or economic aspects which devalues democratic impulses and dissolves them in the market challenges. It threatens the understanding of democracy as the fundamental segment of our rights and freedom and at the same time leads to revision of the significance and tasks of education (Aronowitz Stanley, 2000, p. 334).

\section{CONCLUSIONS}

To sum up, I would like to emphasize the challenges to the classical university model in the XXI century. First is the innovative character of the modern world which, unlike previous centuries, is constantly changing and aims for the future as its basic ontological value. The most appropriate way to meet this challenge is to develop research universities which are often regarded as world-class ones. Second is the commercialization of academic life tightly connected to the process of globalization and turning a university into an international institution. The challenge is met through an entrepreneurial and corporate university.

\section{REFERENCES}

1. Buravoy, M. (2014). Phenomenon of inequality: challenges for university education (conversation was hold by Sergiy Kurbatov). Retrieved from http:// www.philosopheducation.com/images/Files/PDF/2014_issue_2/2_15_9.pdf

2. Gadamer, H.-G. (2002). The idea of the University - yesterday, today and tomorrow. The idea of the university: Anthology. Lviv: Litopys.

3. Humboldt, W. (2002). On the internal and external organization of higher academic institutions in Berlin. The idea: Anthology. Lviv: Litopys.

4. Kurbatov, S. (2014). The phenomenon of the university in the context of time and space challenges: Monograph. Sumy: Universytetska Knyga.

5. Polyakov, M. (2004). Classical University. Evolution, Current State. Kyiv: Geneza.

6. Kremen, V. (ed.). The phenomenon of innovations: education, society, culture: monograph. Kyiv: Pedagogichna dumka.

7. Shnedelbah, H. (2002). Humboldt University. Logos, 5-6 (35), 1-14.

8. Jaspers, K. (2002). The idea of University. The idea of the university: anthology. Lviv: Litopys.

9. Altbach, P. (2011). The Road to Academic Excellence: The Making of WorldClass Research Universities.

10. Academic Ranking of World Universities. Retrieved from http://www. shanghairanking.com/ARWU2016.html

11. Academic Ranking of World Universities: Statistics. Retrieved from http:// www.shanghairanking.com/ARWU-Statistics-2016.html

12. Aronowitz, S., Giroux H. (2000). The Corporate University and the Politics of Education. The Educational Forum, 4, 332-339.

13. Atkinson, R., Blanpied, W. (2008). Research Universities: Core of the US Science and Technology System. Technology in Society, 30, 30-48. 
14. Carnegie Classifications. Retrieved from http://carnegieclassifications.iu.edu

15. Etzkowitz, H. (2013). When Knowledge Married Capital: The Birth of Academic Enterprise.Journal of Knowledge-based Innovation in China, 5 (1), 44-59.

16. Harvard at a Glance. Retrieved from http://www.harvard.edu/ about-harvard/harvard-glance

17. Hearn, D. An Examination of Corporate University Model. Retrieved from http://www.newfoundations.com/OrgTheory/Hearn721.html

18. Meister, J. (1998). Corporate Universities: Lessons in Building a World-Class Work Force. McGraw-Hill.

19. Rademakers, M. (2005). Corporate Universities: Driving Force of Knowledge Innovation. The Journal of Workplace Learning, 17, 130-136.

20. Rothaermel, F. (2007). University Entrepreneurship: A Taxonomy of the Literature. Industrial and Corporate Change, 16 (4), 691-791.

21. Scott, J. The Mission of the University: Medieval to Postmodern Transformations. The Journal of Higher Education. Special Issue: Moving into the Next 75 Years, 77 (1), 1-39. 